\title{
Correction to: Induction of immunogenic cell death in radiation-resistant breast cancer stem cells by repurposing anti- alcoholism drug disulfiram
}

Ting Sun ${ }^{1,2}$, Wei Yang ${ }^{3,4}$, Sneh M. Toprani ${ }^{3}$, Wei Guo ${ }^{1}$, Lile He ${ }^{1}$, Albert B. DeLeo ${ }^{1}$, Soldano Ferrone ${ }^{1,5}$, Gong Zhang ${ }^{1}$, Enwen Wang ${ }^{1}$, Zunwen Lin ${ }^{1}$, Pan $\mathrm{Hu}^{1}$ and Xinhui Wang ${ }^{1 *}$

\section{Correction to: Cell Commun Signal (2020) 18:36 https://doi.org/10.1186/s12964-019-0507-3}

Following publication of the original article [1], the authors reported an error in the section Mammosphere formation assay. $5 \mathrm{mg} / \mathrm{mL}$ insulin should be $5 \mu \mathrm{g} / \mathrm{mL}$ insulin. The second sentence should therefore read as follows:

The medium contained 32\% MethoCult medium, 20\% MammoCult basal human medium with a final concentration of $2 \%$ MammoCult proliferation supplements and 48\% DMEM supplemented with final concentrations of $100 \mathrm{pg} / \mathrm{mL}$ EGF, $50 \mathrm{ng} / \mathrm{mL}$ bFGF, $5 \mathrm{ng} / \mathrm{mL}$ stem cell factor, $1 \mu \mathrm{M}$ hydrocortisone, and $5 \mu \mathrm{g} / \mathrm{mL}$ insulin, all obtained from STEMCELL Technologies.

The authors apologise for this error.

\section{Author details}

${ }^{1}$ Division of Surgical Oncology, Department of Surgery, Massachusetts General Hospital, Harvard Medical School, Boston, USA. ${ }^{2}$ Neurosurgery and Brain and Nerve Research Laboratory, The First Affiliated Hospital of Soochow University, Suzhou, Jiangsu, China. ${ }^{3}$ John B. Little Center for Radiation Sciences, Harvard T.H. Chan School of Public Health, Boston, USA.

${ }^{4}$ State Key Laboratory of Radiation Medicine and Protection, School of
Radiation Medicine and Protection and Collaborative Innovation Center of Radiation Medicine of Jiangsu Higher Education Institutions, Soochow University, Suzhou, China. ${ }^{5}$ Department of Orthopaedic Surgery,

Massachusetts General Hospital, Harvard Medical School, Boston, USA.

Published online: 02 April 2020

Reference

1. Sun T, Yang W, Toprani SM, et al. Induction of immunogenic cell death in radiation-resistant breast cancer stem cells by repurposing anti-alcoholism drug disulfiram. Cell Commun Signal. 2020;18:36 https://doi.org/10.1186/ s12964-019-0507-3.

The original article can be found online at https://doi.org/10.1186/s12964019-0507-3

* Correspondence: Xwang30@mgh.harvard.edu

${ }^{1}$ Division of Surgical Oncology, Department of Surgery, Massachusetts General Hospital, Harvard Medical School, Boston, USA

Full list of author information is available at the end of the article

C C The Author(s). 2020 Open Access This article is licensed under a Creative Commons Attribution 4.0 International License, which permits use, sharing, adaptation, distribution and reproduction in any medium or format, as long as you give appropriate credit to the original author(s) and the source, provide a link to the Creative Commons licence, and indicate if changes were made. The images or other third party material in this article are included in the article's Creative Commons licence, unless indicated otherwise in a credit line to the material. If material is not included in the article's Creative Commons licence and your intended use is not permitted by statutory regulation or exceeds the permitted use, you will need to obtain permission directly from the copyright holder. To view a copy of this licence, visit http://creativecommons.org/licenses/by/4.0/ The Creative Commons Public Domain Dedication waiver (http://creativecommons.org/publicdomain/zero/1.0/) applies to the data made available in this article, unless otherwise stated in a credit line to the data. 